\title{
ナノ構造制御による有機－無機ナノ複合材料の開発
}

\author{
山田保 治*
}

\section{Development of Organic-Inorganic Nanocomposites and Hybrid Materials by Controlling the Nanostructures}

Yasuharu YAMADA (Techno-Innovation Center, Nagoya Institute of Technology, Gokiso-cho, Showa-ku, Nagoya 4668555, Japan)

Preparation and properties of nanocomposite and hybrid materials based on poly(methyl methacrylate) (PMMA) and silica were reviewed. The materials are mainly prepared by intercalation, sol-gel and in-situ polymerization methods, and generally have improved thermal and thermo-oxidative stability, mechanical properties, and hardness by incorporating silica component into polymer matrix. Good transparency is obtained when silica nanoparticle is used and finely dispersed in polymer matrix or the strong interaction exists between organic and inorganic phases to enhance the phase miscibility. The strong interaction between two phases is caused by the formation of covalent bonds between PMMA and silica moieties and hydrogen bonds between carbonyl group in PMMA and silanol group in silica surface. The materials are defined as nanocomposites without any or week interaction and as hybrids with strong interaction between two components respectively.

Surface-functionalized silica is also prepared by reacting silica nanoparticle and silane coupling agents, followed by sol-gel or in-situ polymerization to afford hybrid materials. Properties of the materials varies by controlling the nanostructures and morphologies of the materials.These materials have potential for molding, coating, optical device, and separation applications, and are expected further new applications by controlling the nanostructure and introducing functionality into the molecule.

Key Words : Nanocomposite, Hybrid, PMMA, Sol-gel reaction, In-situ polymerization, Nanostructure

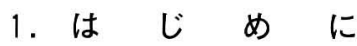

次世代のキーテクノロジーとして期待されるナノテクノ ロジーは, 日米欧でエレクトロニクス, 情報通信, バイオ， 環境・エネルギー，材料など幅広い分野で研究開発が行わ れている．我が国でも2001年より発足した第 2 次科学技 術基本計画の 4 大重点分野にナノテクノロジー・材料が取 り上げられ，その研究成果に大きな期待が寄せられている. 高分子材料分野でも近年，有機化合物 (ポリマー) と無機化 合物をナノレベルで複合化した新規な有機一無機ナノ複合 材料の開発が盛んに行われている ${ }^{1-3)}$.これらの材料はナ ノコンポジットあるいはナノハイブリッド(有機－無機ハ イブリッド)とも言われ先端機能材料のひとつとして注目 されているが，有機，無機雨成分を原子・分子レベル(ナ ノスケール)で複合化し，ポリマーがもつ柔軟性(成型性) や機能性と無機化合物がもつ耐熱性, 耐薬品性や硬度を兼
ね備えた高機能材料を創製しようとするものである，表 1 にポリマーとシリカを複合化したときの複合材料の一般的 な特性の変化をまとめた．複合化することによって向上す る特性と低下する特性があり，開発目標を明確に最適な分 子設計 (材料設計)を行うことが重要である.

有機 一無機ナノ複合材料は 1980 年代に層間挿入法(層剥 離法)を中心に開発が進められ，90年代にゾルーゲル法の 開発研究が進められ今日に至っている。これらの中には既 にいくつかの有機－無機ナノ複合材料が工業化されている

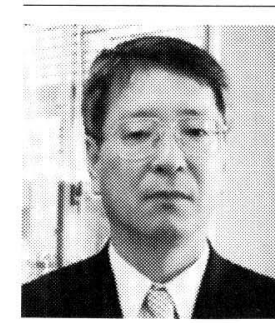

*名古屋工業大学テクノイノベーションセンタ 一( ( 466 -8555 名古屋市昭和区御器所町) 教 授, 工博. 昭和 48 年, 京都大学大学院工学研 究科石油化学専攻修了. 同年, 住友化学工業 株入社. 平成 12 年, 名古屋工業大学教授, 現 在に至る. 専門は, 高分子材料科学, 機能性 高分子合成. 
表 1 シリカと複合化することによる特性変化

\begin{tabular}{|c|c|}
\hline 特 性 & 効 果 \\
\hline \multicolumn{2}{|l|}{ 熱 特 性 } \\
\hline 熱分解温度 & $\uparrow$ \\
\hline ガラス転移温度 & $\uparrow$ \\
\hline 熱膨張係数 & $\downarrow$ \\
\hline \multicolumn{2}{|l|}{ 機 械 特 性 } \\
\hline 引張強度 & $\uparrow(\downarrow *)$ \\
\hline 引張弾性率 & $\uparrow$ \\
\hline 伸び & $\downarrow$ \\
\hline 耐摩耗性 & $\uparrow$ \\
\hline \multicolumn{2}{|l|}{ その他の特性 } \\
\hline 表面硬度 & $\uparrow$ \\
\hline 耐薬品性 & $\uparrow$ \\
\hline 比誘電率 & $\uparrow$ \\
\hline 密着・接着性 (ガラス, SUS, フィルム) & $\uparrow$ \\
\hline 気体透過性 & $\uparrow$ \\
\hline
\end{tabular}

表 2 工業化された代表的な有機一無機ナノ複合材料

\begin{tabular}{l|l|l}
\hline \multicolumn{1}{c|}{ ポリマー } & \multicolumn{1}{|c}{ 無 機 成 分 } & \multicolumn{1}{c}{ 途 } \\
\hline $\begin{array}{l}\text { アクリル樹脂 } \\
\text { (PMMA) }\end{array}$ & $\mathrm{SiO}_{2}$ & 塗料, コーティング剤 \\
\hline エポキシ樹脂 & $\mathrm{SiO}_{2}$ & 電気・電子材料 \\
\hline ウレタン樹脂 & $\begin{array}{l}\text { ポリアルコキシシロキ } \\
\text { サン }\end{array}$ & 接着剤, 塗料, 電子材料 \\
\hline ポリイミド(PI) & $\begin{array}{l}\text { ポリアルコキシシロキ } \\
\text { サン }\end{array}$ & 接着剤, 電子材料 \\
\hline $\begin{array}{l}\text { ポリカーボネート } \\
\text { (PC) }\end{array}$ & カーボンナノチューブ & 導電性材料, 成形材料 \\
\hline $\begin{array}{l}\text { シリコーンゴム } \\
\text { (PDMS) }\end{array}$ & $\begin{array}{l}\text { 炭素粒子/ } \\
\text { セラミックス微粒子 }\end{array}$ & センサー \\
\hline $\begin{array}{l}\text { ポリアミド } \\
\text { (ナイロン) }\end{array}$ & カーボンナノファイバー & 成形材料 \\
\hline $\begin{array}{l}\text { ポリアミド } \\
\text { (ナイロン) }\end{array}$ & クレー & 成形材料 \\
\hline
\end{tabular}

(表 2 ).

本稿では，ゾルーゲル法抒よび微粒子分散法によるポリ メチルメタクリレート (PMMA)を有機成分とするシリカ とのナノ複合材料の現状と今後の展望について述べる.

\section{2. 有機-無機ナノ複合材料の合成}

有機一無機ナノ複合材料には多くの合成法が報告されて いるが，大別して表 3 に示した方法が挙げられる.

これらの方法で最も簡易な合成法は, 無機超微粒子をポ リマーと溶液中直接混合 (溶液混合法)または溶融混練 (溶 融混練法)する方法であるが，溶液混合法はコストが高く つくため大量生産の工業プロセスには適さず, 溶融混練法 は超微粒子を二次凝集させず，均一に分散させることが困 難である．また，ポリマー溶液中で金属アルコキシドをゾ ルーゲル反応させる合成法 (ゾルーゲル法) や無機微粒子存 在下にモノマーを重合させる合成法(In-Situ重合法)も， 溶液混合法や溶融混練法に比べると無機成分 (超微粒子) を

\section{表 3 有機一無機ナノ複合材料の合成法}

1. 層間挿入法(層剥離法)

クレーやマイカなどの無機層状化合物をアルキル 4 級アンモニ ウム塩などの有機変性剤で変性し，モノマーと重合（重合法）また はポリマーと溶融混練(溶融混練法)し, 層剥離と分散を起こさせ る方法

2. ゾル-ゲル法

ポリマー溶液中で金属アルコキシドをゾル-ゲル反応させ，無 機酸化物を分散させる方法

3. 超微粒子分散法

・無機超微粒子とポリマーを溶液中直接混合 (溶液混合法)または 溶融混練(溶融混練法)させる方法

・無機超微粒子存在下にモノマーを重合させる方法 (In-Situ 重合 法)

より均一にポリマー中に分散させる比較的容易な合成法と してよく利用される.

一般に，ポリマーと無機超微粒子は表面エネルギーの違 いが大きく相容性がない，また，無機超微粒子は表面エネ ルギーが大きく，表面積も大きいため二次凝集を起こしや すい．このため, 超微粒子の表面をシランカップリング剂 などで化学処理(カップリング処理)して表面エネルギーを 低下させ，二次凝集を防止するとともにポリマーとの相互 作用を高め複合化することも行われる.

ゾルーゲル法やIn-Situ重合法では，合成法によってポ リマーと無機成分 (超微粒子) 間に相互作用のないナノ複合 材料と共有結合や水素結合など両成分間に強い相互作用の あるナノ複合材料が創製できる．相互作用のない有機一無 機ナノ複合材料を(ナノ)コンポジット $(\mathrm{NC})$, 相互作用の ある有機－無機ナノ複合材料を(ナノ)ハイブリッド(HBD) と言うこともあるが，明確な定義は未だなされていない。

いずれの方法にしろ, 高性能・高機能な有機一無機ナノ 複合材料の合成は，ポリマーと無機成分との相互作用を高 め, いかに無機成分(超微粒子)をポリマー中にナノスケー ルで均一に分散させるかが鍵となる。

\section{1 ゾル-ゲル法}

ゾルーゲル反応はケイ素, チタン, ジルコニウム, アル ミニウムなどの金属アルコキシドと水とを酸あるいは塩基 触媒とともに反応させ，比較的低温で金属酸化物 (無機ガ ラス）を合成する反応である ${ }^{4)}$. ポリマー存在下にゾルー ゲル反応を行うと有機一無機ナノ複合材料が合成できる.

ゾルーゲル法による有機 一無機ナノ複合材料の合成で は，その反応条件によって生成する無機酸化物の粒子サイ ズや微細構造が大きく異なり，有機一無機ナノ複合材料の 物性も変化する(表 4 ). 高性能・高機能な有機一無機ナ八 複合材料を合成するためには，この反応条件を最適化する ことが重要であり, 反応条件によって有機一無機ナノ複合 材料の物性を制御することができる.

ポリマーと無機成分が共有結合した有機一無機ハイブリ ッドを合成するには，ポリマー分子内あるいは分子末端に 
トリアルコキシ基を導入し，金属アルコキシ化合物とゾ ルーゲル反応を行わせて合成する. 具体的には, (メ夕)ア クリル酸エステル, 酢酸ビニルやスチレンなどのビニル化 合物とビニルトリアルコキシシランやメタクリロキシプロ ピルトリアルコキシシランを共重合する方法や, ポリマー と図 1 に示すようなシランカップリング剤を反応させ，分 子内あるいは分子末端にアルコキシシリル基を導入する方 法がよく使用される

このようにして分子内 (あるいは分子末端)に導入したア ルコキシシリル基がゾルーゲル反応によって無機成分との 結合部位(架橋点)になり，ポリマーと無機化合物の間に金

\section{表 4 ゾルーゲル法による粒子サイズ・ナノ構造の制御}

1. 加水分解と重縮合は並行して進行

2. 置換基(アルコキシ基)の大きさにより加水分解速度が異なる

3. 触媒 (酸・塩基)により加水分解機構が異なり, ゲル構造が変化 酸触媒: アルコキシ基の酸素がプロトン化される段階(親電子 反応) が律速

塩基触媒：金属 (ケイ素)への求核攻撃 (求核反応)が律速

4. 加水分解条件 (濃度, 水分濃度, 温度, 触媒)によりゲルの微細 構造が変化

酸触媒・水分が少ない条件：架橋密度が低い

酸触媒・水分が多い条件: 架橋密度が高く, 均一性の高い網目 構造

塩基触媒・水分が少ない条件 : 不均一な網目構造

塩基触媒・水分が多い条件 : 架橋密度が高く, 3 次元的な粗い 網目構造

5. 熱処理(乾燥)条件の違いによりコンポジット(ハイブリッド)物 性が変化

高い熱処理温度：ゲル内部・表面の水酸基濃度が減少 (金属酸素結合 (シロキサン結合)の増加）
属 一酸素結合 (シロキサン結合など)が形成される.

\subsection{In-Situ 重合法}

無機超微粒子存在下でモノマーを重合させ複合化する方 法は最も簡易で安価な万法の一つであるが，ポリマーと無 機化合物との間に水素結合や共有結合などの相互作用がな ければ複合化の効果が十分に得られない。このため，無機 超微粒子の表面を末端にビニル基などの重合性基をもつ化 学修飾剂 (シランカップリング剂など)で表面処理し, 無機 超微粒子とポリマーとの間に結合部位 (架橋点)をもたせる 方法が使用される．無機超微粒子表面には多くの水酸基が 存在するため, この水酸基と反応する置換基 (アルコキシ シリル基，水酸基，カルボン酸，酸ハライド，グリシジル 基，イソシアネート基など）をもつ化合物が化学修飾剂と して使用される。このようにして調製した表面改質超微粒 子存在下にモノマーを重合させ，無機成分とポリマー間に 共有結合を形成させ，いわゆるコアーシェル構造をもつ有 機一無機ハイブリッドを合成する.

\section{3. ポリメチルメタクリレート-シリカ複合材料}

PMMA は透明性，耐候性，成型性に優れた樹脂で有機 ガラスとも言われ，自動車部品，ディスプレイ材料やプラ スチックレンズなど工業的に広く使用されている。しかし ながら，耐熱性や耐衝撃性が低く，表面に傷がつきやすい などの欠点をもっている。このため，PMMAの透明性を 低下させず耐熱性，機械的強度や表面特性を向上させた PMMA - シリカ複合材料が数多く開発されている．特に，

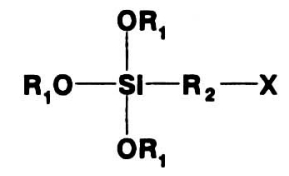

$\mathrm{X}:-\mathrm{NH} 2,-\mathrm{OH},-\mathrm{NCO},-\mathrm{COOH},-\mathrm{COCl},-\mathrm{CH}=\mathrm{CH}_{2}$,

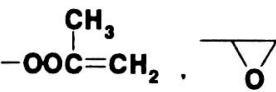

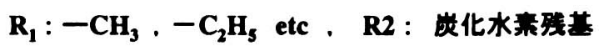

図 1 代表的なシランカップリング剂
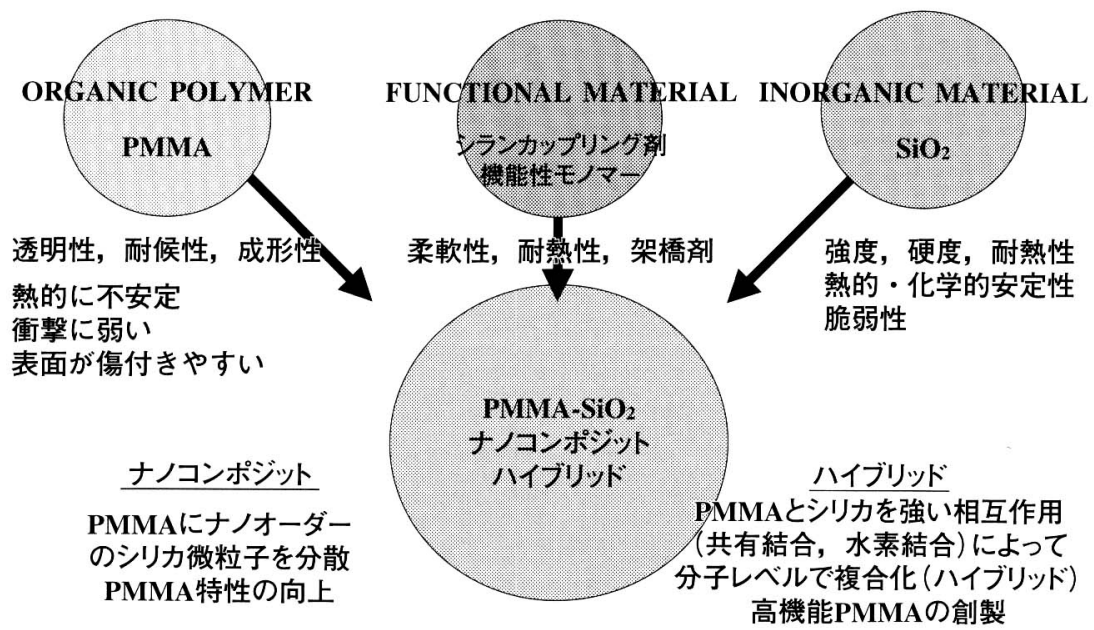

図 2 PMMAの高性能化・高機能化 
PMMAの屈折率 $(1.49)$ はシリカの屈折率 $(1.4 \sim 1.5)$ に比較 的近く, 両成分間の屈折率の違いから起こる光の界面反射 が起こりにくい，そのため，粒子径が光の波長よりも極め て小さなナノ粒子を複合化することによって透明な複合材 料を合成することが容易である．図 2 にPMMAの高性能 化・高機能化の観点から有機－無機ナノ複合材料の開発に ついてまとめた.

3.1 ゾル-ゲル法による PMMA-シリカハイブリッドの 合成

ゾルーゲル法を利用したPMMA - シリカハイブリッド (PMMA $\left.-\mathrm{SiO}_{2} \mathrm{HBD}\right)$ は, 一般に MMA とビニルトリメト キシシランやメタクリロキシプロピルトリメトキシシラン (MPS) などのアルコキシシリル基をもつビニル化合物と を共重合させポリマー主鎖にアルコキシシリル基を導入

\section{Polymerization}

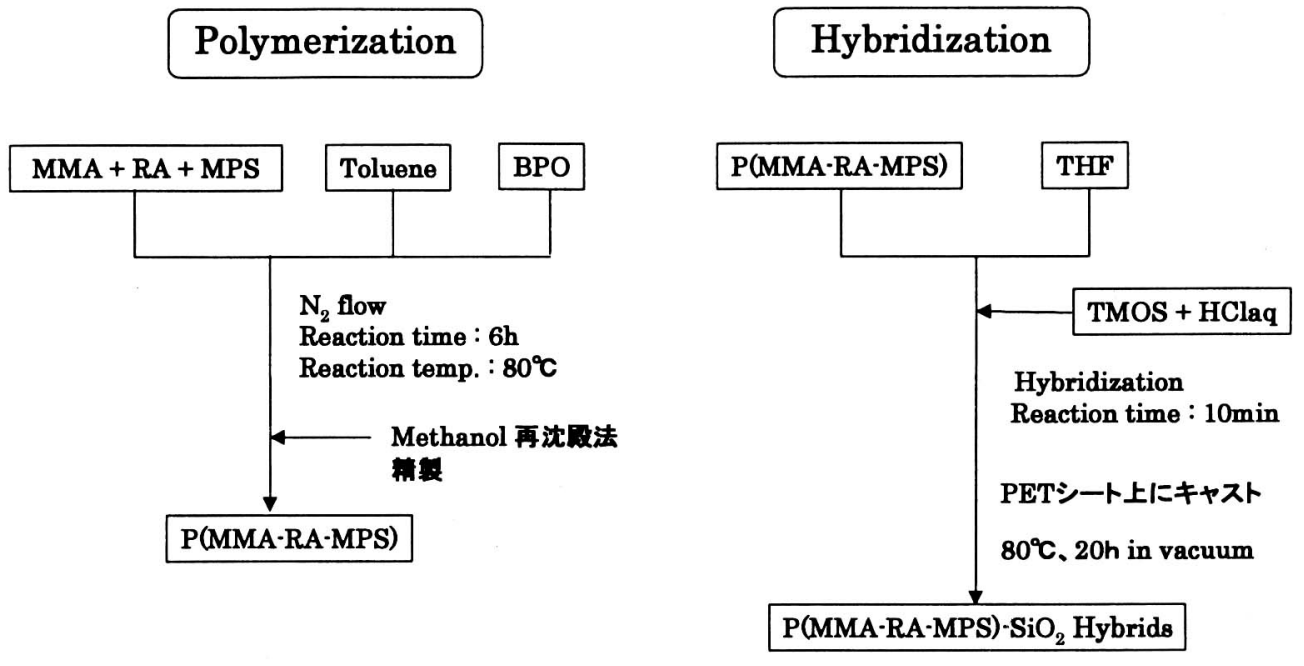

し, その後シリケートと水を加え, 酸触媒(塩酸, 硝酸な ど）または塩基触媒（アンモニアなど）の存在下にゾルーゲ ル反応させて合成する。このようにして合成された HBD はPMMAとシリカとの間に共有結合をもった相容性の高 いものである。PMMA 溶液中で直接シリケートをゾルー ゲル反応させて合成する方法もあるが, PMMAとシリカ 間に相互作用がないため，得られる複合材料は一般に不透 明でもろい。

我々は，MMA とMPSをラジカル開始剤 (AIBN，BPO など)で共重合後，テトラメトキシシラン (TMOS) と水 (触媒として塩酸を使用)を加え, ゾルーゲル法によって PMMA- $\mathrm{SiO}_{2} \mathrm{HBD}$ を合成した。また，MMA，アクリル酸 エステル $(\mathrm{RA})$ と MPSを共重合させたゴム変性PMMAを 合成し, 同様にゾルーゲル法によって $\mathrm{P}(\mathrm{MMA}-c o-\mathrm{RA})-$

図 3 ゾルーゲル法による $\mathrm{P}(\mathrm{MMA}-\mathrm{RA}-\mathrm{MPS})-\mathrm{SiO}_{2} \mathrm{HBD}$ の合成

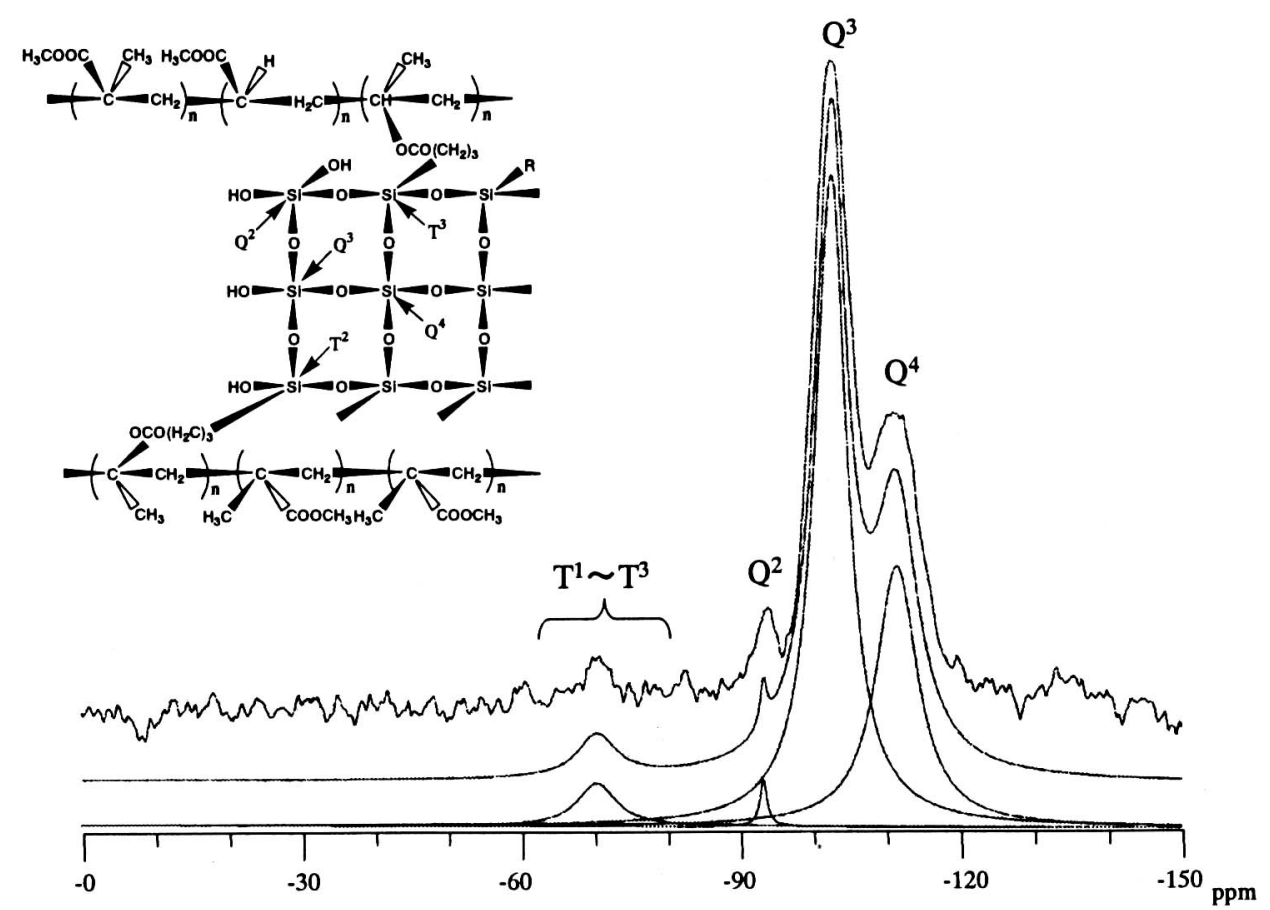

図 $4 \mathrm{P}$ (MMA-MA10-MPS3)- $\mathrm{SiO}_{2}$ ハイブリッド $\left(\mathrm{SiO}_{2}: 30 \mathrm{wt} \%\right)$ の固体 ${ }^{29} \mathrm{Si}$ MAS NMR スペクトルと波形解析 
$\mathrm{SiO}_{2} \mathrm{HBD}$ も合成した。いずれの HBD もシリカ含有量が 30 $\mathrm{wt} \%$ 程度までは透明でフィルム形成が可能な HBD が合成 でき, 耐熱性, 機械的強度, 表面硬度を改良できることを 明らかにした ${ }^{6)}$. 図 3 に $\left(\mathrm{MMA}-\mathrm{Co}^{-\mathrm{RA}}\right)-\mathrm{SiO}_{2} \mathrm{HBD}$ の合 成法を示す。

ゾルーゲル法で合成された HBDの特性は, HBDの熱処 理温度によって変化する。一般に,ゾルーゲル反応は室温 付近の低温で反応させるが，このとき生成するシリカゲル は分子内に多くの水酸基を含有し, シロキサン結合の形成 が十分に進行していない.このため, 反応後熱処理するこ とによってゲル中のシロキサン結合の形成を進行させ，架 橋構造 (シリカネットワーク)を完結させることが必要であ る.ゾルーゲル法で合成後, $80{ }^{\circ} \mathrm{C}\left(\right.$ ベースポリマーの $T_{\mathrm{g}}$ 以 下の温度)で熱処理した $\mathrm{PMMA}-\mathrm{SiO}_{2} \mathrm{HBD}$ および $\mathrm{P}(\mathrm{MMA}$ $-c o-\mathrm{RA})-\mathrm{SiO}_{2} \mathrm{HBD}$ の引張強度と伸びはシリカ含有量と ともにやや低下し, 引張弾性率はシリカ含有量とともに若 干向上した. HBDの熱分解温度 $\left(T_{\mathrm{d}}\right)$, ガラス転移温度 $\left(T_{\mathrm{g}}\right)$, 密度, 表面硬度, 接触角はシリカ含有量の増加および熱処 理温度の上昇とともに向上した. HBDのシリカゲル中の 水酸基濃度が比較的高くシロキサン結合が不完全な HBD では, シリカによるポリマーの可塑化が起こり，力学特性 を低下させる要因になる。

我々はまた, $\mathrm{P}(\mathrm{MMA}-\mathrm{MA} 10-\mathrm{MPS} 3)-\mathrm{SiO}_{2} \mathrm{HBD}$ (数字 は共重合体中の組成 (モル\%)を示す)中のシリカの結合状 態をFT-IR および固体 ${ }^{29} \mathrm{Si}$ MAS NMRで解析し, HBD 中 のシリカ微細構造と特性の関係を明らかにした。図 4 に (MMA-MA10-MPS3)- $\mathrm{SiO}_{2}$ HBDの固体 ${ }^{29} \mathrm{Si}$ MAS NMRスペクトルを, 表 5 に化学シフト值および相対面積 強度をまとめたＨBD中のシロキサン結合の割合はシリ 力含有量の増加および熱処理温度の上昇とともに増加し, シリカの縮合反応が進行するとともにシリカネットワーク がより強固に形成されていることがわかる.

PMMA - シリカ HBD では, シリカ含有量の少ない領域 においてはシリカドメインによる PMMAへの束縛効果が 小さい上, シリケートの縮合反応が不十分な場合は強固な シリカネットワークが形成されず，残存する運動性の高い
シラノール基によるポリマーへの可塑化効果が起こり HBDの特性を十分に得られない。したがって, ゾルーゲ ル法による HBD 合成においては，ポリマーと無機成分間 の相互作用を高め, HBD 中にナノレベルの強固なシリカ ネットワークを形成することが重要である.

Chang らは, MMAとMPS共重合体にシリケートと 種々のトリアルコキシシランを加え, ゾルーゲル法によっ て合成した HBDの ${ }^{29} \mathrm{Si} \mathrm{NMR}$ 測定から HBD 中のシリカ構 造を解析し, シリカ含有量の増加にしたがってシリカの縮 合度が減少すると報告している ${ }^{7)}$ 。また, 測定結果から算 出したスピン拡散距離は約 $3.6 \mathrm{~nm}$ であり, HBD 中の PMMAとシリカ成分はナノメータースケールで相容して いることを明らかにしている。

Chanらは, PMMA存在下にテトラエトキシシラン (TEOS)をゾルーゲル反応させて $\mathrm{PMMA}-\mathrm{SiO}_{2} \mathrm{HBD}$ を合 成し， $180{ }^{\circ} \mathrm{C}$ で熱処理したPMMA- $\mathrm{SiO}_{2} \mathrm{HBD}$ が高い相容 性を示すこと, およびPMMAのカルボニル基とシリカの シラノール基との間に水素結合が存在し，この水素結合と 熱処理が高い相容性を発現させていると述べているが, HBDの透明性については示していない ${ }^{8)}$.

一般に，ゾルーゲル法による HBDの合成においては， 分子レベルで有機, 無機成分を分散, 複合化できるため両 成分間の相互作用が大きく，また，ゾルーゲル反応条件を 選択することによってシリカの微細構造が制御できること など，優れた特性をもったHBD を合成することができる.

\subsection{In-Situ 重合法による PMMA-シリカナノコンポジ ットの合成}

近年，粒子径が $10 〜 20 \mathrm{~nm}$ のシリカ超微粒子 (コロイダ
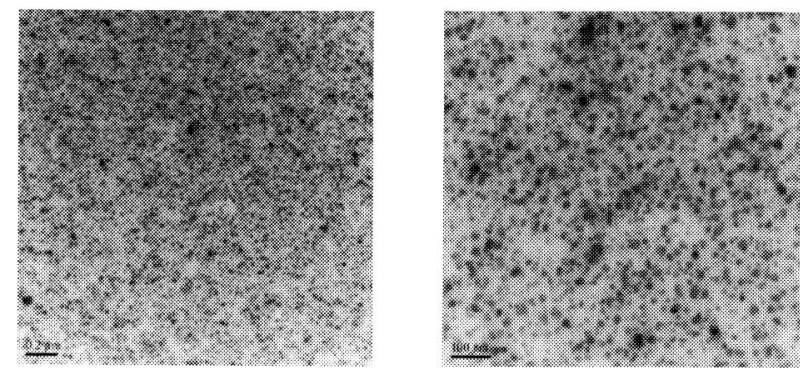

図 5 PMMA- $\mathrm{SiO}_{2} \mathrm{NC}$ の TEM写真 $\left(\mathrm{SiO}_{2}: 10 \mathrm{wt} \%\right)$

表 5 P (MMA-MA10-MPS3)- $\mathrm{SiO}_{2} \mathrm{HBD}$ フィルムの固体 ${ }^{29} \mathrm{Si}$ MAS NMR 測定結果

\begin{tabular}{|c|c|c|c|c|c|c|c|c|}
\hline \multirow[b]{2}{*}{ Sample } & \multirow{2}{*}{$\begin{array}{c}\mathrm{SiO}_{2} \\
\text { contents }\end{array}$} & \multirow{2}{*}{$\begin{array}{c}\text { Heart } \\
\text { treatment }\end{array}$} & \multicolumn{3}{|c|}{ Chemical Shifts [ppm] } & \multicolumn{3}{|c|}{ Relative Proportions [\%] } \\
\hline & & & $\mathrm{Q}^{2}$ & $\mathrm{Q}^{3}$ & $\mathrm{Q}^{4}$ & $\mathrm{Q}^{2}$ & $Q^{3}$ & $\mathrm{Q}^{4}$ \\
\hline $\mathrm{P}(\mathrm{MMA}-\mathrm{MA} 10-\mathrm{MPS} 3)-\mathrm{SiO}_{2}$ & $10 \mathrm{wt} \%$ & $80^{\circ} \mathrm{C}$ & -91.97 & -101.69 & -110.37 & 6.0 & 59.2 & 34.9 \\
\hline $\mathrm{P}(\mathrm{MMA}-\mathrm{MA} 10-\mathrm{MPS} 3)-\mathrm{SiO}_{2}$ & $20 \mathrm{wt} \%$ & $80^{\circ} \mathrm{C}$ & -93.00 & -102.27 & -111.17 & 3.1 & 68.5 & 28.4 \\
\hline $\mathrm{P}(\mathrm{MMA}-\mathrm{MA} 10-\mathrm{MPS} 3)-\mathrm{SiO}_{2}$ & $30 \mathrm{wt} \%$ & $80^{\circ} \mathrm{C}$ & -93.43 & -102.61 & -111.55 & 1.1 & 65.4 & 33.6 \\
\hline $\mathrm{P}(\mathrm{MMA}-\mathrm{MA} 10-\mathrm{MPS} 3)-\mathrm{SiO}_{2}$ & $10 \mathrm{wt} \%$ & $120^{\circ} \mathrm{C}$ & -93.00 & -101.92 & -110.18 & 3.4 & 44.3 & 52.2 \\
\hline $\mathrm{P}(\mathrm{MMA}-\mathrm{MA} 10-\mathrm{MPS} 3)-\mathrm{SiO}_{2}$ & $20 \mathrm{wt} \%$ & $120^{\circ} \mathrm{C}$ & -91.14 & -101.71 & -110.16 & 1.2 & 66.9 & 31.9 \\
\hline $\mathrm{P}(\mathrm{MMA}-\mathrm{MA} 10-\mathrm{MPS} 3)-\mathrm{SiO}_{2}$ & $30 \mathrm{wt} \%$ & $120^{\circ} \mathrm{C}$ & -92.99 & -102.43 & -110.74 & 0.2 & 63.9 & 35.9 \\
\hline $\mathrm{P}(\mathrm{MMA}-\mathrm{MA} 10-\mathrm{MPS} 3)-\mathrm{SiO}_{2}$ & $10 \mathrm{wt} \%$ & $150^{\circ} \mathrm{C}$ & -91.74 & -101.48 & -109.55 & 1.8 & 45.0 & 53.2 \\
\hline $\mathrm{P}(\mathrm{MMA}-\mathrm{MA} 10-\mathrm{MPS} 3)-\mathrm{SiO}_{2}$ & $20 \mathrm{wt} \%$ & $150^{\circ} \mathrm{C}$ & -91.74 & -101.41 & -109.27 & 0.2 & 66.0 & 33.8 \\
\hline P(MMA-MA10-MPS3)- $\mathrm{SiO}_{2}$ & $30 \mathrm{wt} \%$ & $150^{\circ} \mathrm{C}$ & -92.64 & -101.79 & -109.61 & 0.2 & 56.9 & 42.9 \\
\hline
\end{tabular}


ルシリカ)が工業的に製造され容易に入手できるようにな った。この超微粒子シリカを直接PMMA と複合化し，透 明で諸特性に優れたナノコンポジットが合成できれば，安 価で工業的に製造可能な工業材料が製造できる.

我々は，表面改質をしていないコロイダルシリカ(粒子 径：10〜20nm)をMMA 中に分散させ，ラジカル開始剤 でバルク重合，あるいはMMA と RAをバルク共重合させ， 透明性を低下させずに耐熱性，機械的強度，表面硬度を改 良したPMMA - シリカナノコンポジット (PMMA- $\mathrm{SiO}_{2}$ NC) が合成できることを報告した ${ }^{9)}$.これらのナノコンポ ジットはシリカ含有量が $30 \mathrm{wt} \%$ 程度までは高い透明性を 示す。図 5 に $\mathrm{PMMA}^{-\mathrm{SiO}_{2}} \mathrm{NC}$ の TEM写真を示す。シリ 力粒子が凝集することなく PMMA中に均一に分散してい ることが分かる．コロイダルシリカ存在下でのラジカル重 合では，生成するポリマーの分子量はシリカ含有量ととも に増加する。これは生成ラジカルがシリカ表面にトラップ され，重合系内のラジカル実効濃度が低下するためと考え られる ${ }^{10)}$. 引張強度はシリカ含有量が10 wt\%程度までは 向上したが，10 wt\%を超える NCでは低下した。これは 複合化したシリカの表面積が大きく，シリカ含有量の増加 にしたがってPMMAとシリカとの接触界面が増大し， PMMA とシリカ粒子間の空隙が全体として増加するため と考えられる．PMMAとシリカ粒子間には水素結合が形 成されると考えられるが，FT-IRからはPMMA中のカル

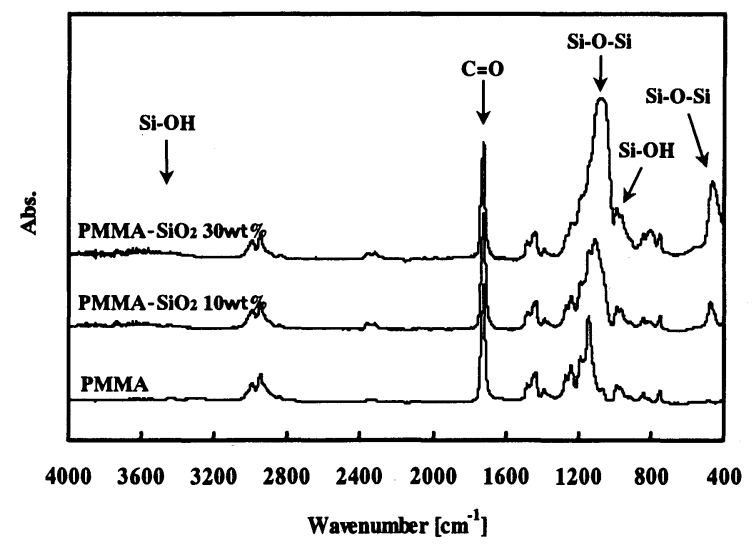

図 6 PMMA，PMMA- $\mathrm{SiO}_{2} \mathrm{NC}$ のIRスペクトル

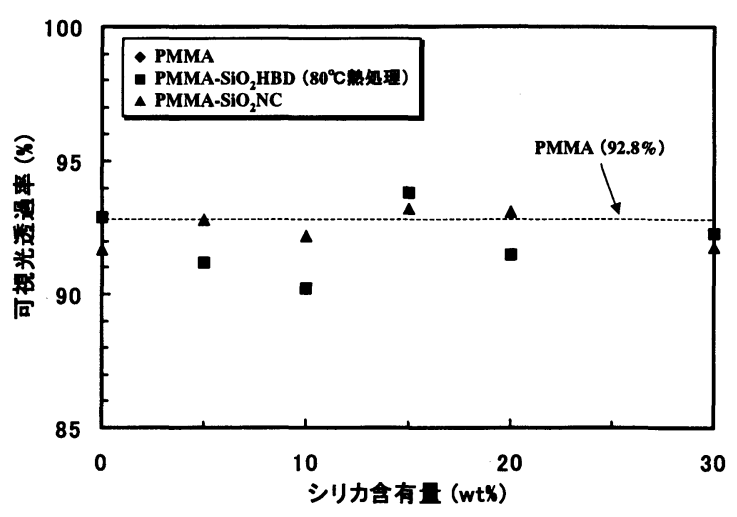

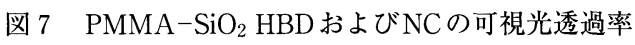

ボニルおよびシリカ表面のシラノールの吸収ピークはほと んどシフトしておらず，In-Situ重合法で合成したPMMA $-\mathrm{SiO}_{2} \mathrm{NC}$ では水素結合は存在してもごく弱いものである と思われる(図 6 )。一方，引張弾性率はシリカ含有量とと もに向上し，伸びは低下した，表面硬度はシリカ含有量の 増加とともに硬くなり，In-Situ重合法による PMMA$\mathrm{SiO}_{2} \mathrm{NC}$ の合成がPMMAの透明性を低下させず，機械的 強度，表面改質に有効であることがわかる．さらに， MMAにRA(アクリル酸メチル (MA)，アクリル酸エチル (EA）およびアクリル酸ブチル $(\mathrm{BA}))$ を共重合し， NCを ゴム変性することによって弾性率を制缻し NCの耐衝撃性 を改良することを試みた。 RA含有量が 30 モル\%程度まで は透明で良好な $\mathrm{P}(\mathrm{MMA}-c o-\mathrm{RA})-\mathrm{SiO} 2 \mathrm{NC}$ が得られたが， 40 モル\%(BAでは30モル\%)ではゲル化した。P(MMA$c o-\mathrm{RA})-\mathrm{SiO}_{2} \mathrm{NC}$ 中の RA含有量が 10 モル\%までは生成ポ リマーの分子量の低下は見られないが，20モル\%以上で は生成ポリマーの分子量は大きく低下した。一般に，RA のバルク重合ではRAの不均化反応が起こり，分子量の低 下と分岐構造を有するポリマーが生成する結果, 架橋して 3 次元網目構造を有するゲルが生成することが知られてい る $^{11)}$. $\mathrm{P}\left(\mathrm{MMA}-c o^{-\mathrm{RA}}\right)-\mathrm{SiO}_{2} \mathrm{NC}$ では，RA含有量が 10 モル\%程度までは引張強度の低下がなく，伸びの増加と引 張弾性率の低下が見られ良好な NCが合成できた。しかし ながら，RAの導入によって表面硬度は $\mathrm{PMMA}-\mathrm{SiO}_{2} \mathrm{NC}$ に比べ低下した。この方法で合成した NCは溶融流動性を 有し, PMMA と同様に射出成形などが可能な成形材料と なる．また, PMMA - シリカナノ複合材料の透明性(可視 光透過率)を図 7 に，表面硬度を図 8 にまとめた.

$\mathrm{Hu}$ らはシリカ表面の疎水性を高めたアルキル(メチルお よびオクチル)修飾シリカ微粒子(アエロジル：粒子径は明 示されていない)をMMA中に分散させ，バルク重合によ って $\mathrm{PMMA}-\mathrm{SiO}_{2} \mathrm{NC}$ 合成し, 熱安定性と弾性率が向上 することを報告している ${ }^{10)}$. 熱安定性の向上はシリカ中 の多数の活性点がPMMA熱分解中のラジカルをトラップ するためと推論している. NCの熱分解性についてはMor-

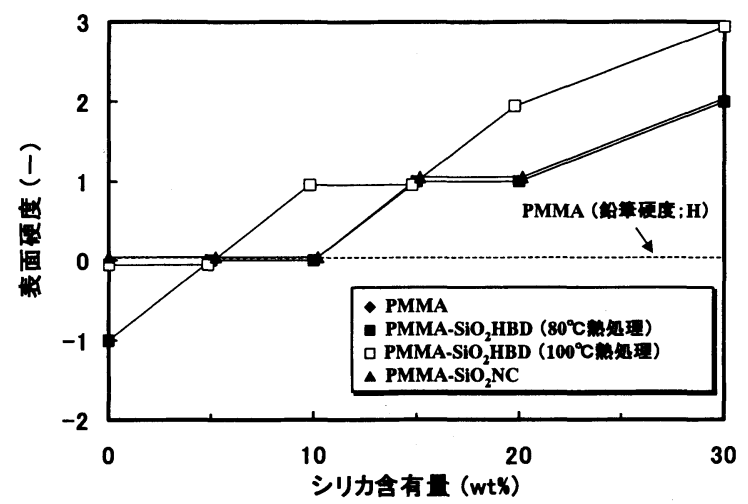

図 8 PMMA- $\mathrm{SiO}_{2} \mathrm{HBD}$ および $\mathrm{NC}$ の表面硬度 
ganらも同様にシリカのラジカルトラッピング効果を提唱 している ${ }^{12)}$. しかし, NC中のシリカ含有量は $4 \mathrm{wt} \%$ で, シリカ含有量の高いNCについては検討しておらず, NCの透明性も明らかにしていない. Aruchamyらは，表 面処理をしていないシリカ微粒子を用いて $\mathrm{PMMA}-\mathrm{SiO}_{2}$ $\mathrm{NC}$ を合成し, PMMA中のカルボニル基とシリカ表面の シラノール基との水素結合の形成が熱安定性を向上させる と論じている13)。また, Kashiwagiらは, コロイダルシリ カ(粒子径：約 $12 \mathrm{~nm}$ ) が均一に分散した透明な PMMA$\mathrm{SiO}_{2} \mathrm{NC}$ を合成し, シリカナノ粒子の添加は熱安定性に顕 著な効果は見られないが弾性率と難燃性が向上することお よびそのメカニズムを報告している ${ }^{14)}$. シリカ粒子添加 による難燃性の発現は, NC 表面近傍での粒子の凝集と粗 粒子の堆積による保護層の形成によるものと考察してい る.この他, PMMA中へのシリカ微粒子の均一な分散性 を高めるため, PMMAを超音波中で重合させる方法や超 臨界炭酸ガス中で重合させる方法などが提案されてい $3^{15)}$.

\subsection{In-Situ 重合法による PMMA-シリカハイブリッド の合成}

シリカ微粒子とポリマーとの相互作用を高めるため, シ リカ表面をシランカップリング剂などで表面処理した後, MMAをIn-Situ重合法によって重合しPMMA とシリカ とを共有結合させた $\mathrm{PMMA}-\mathrm{SiO}_{2} \mathrm{HBD}$ を合成する方法も 数多く報告されている. シリカの表面処理が必要であり, 製造コストは高くなるが $\mathrm{PMMA}-\mathrm{SiO}_{2} \mathrm{NC}$ に比べ特徵ある HBDが合成できる.

MPSで表面改質した単分散コロイダルシリカとMMA から In-Situ重合法によって透明性, 表面平滑性, 熱安定 性, 硬度に優れた $\mathrm{PMMA}-\mathrm{SiO}_{2} \mathrm{HBD}$ フィルムを合成し， 光デバイスへの応用が報告されている ${ }^{16)}$.また, ビスフ エノール A，アリルグリシジルエーテル抽びグリシジル
メタクリレートで表面改質したシリカ微粒子(粒子径： $10-20 \mathrm{~nm})$ を MMA と重合させ, シリカ含有量が70 wt \% を超える透明で表面硬度 $(9 \mathrm{H})$, 表面平滑性抢上び熱安定 性に優れた $\mathrm{PMMA}-\mathrm{SiO}_{2} \mathrm{HBD}$ も合成されている $\left.{ }^{17}, 18\right)$.

2-メタクリロイルオキシエチルイソシアネート (MOI) で表面改質したコロイダルシリカ（粒子径：12 nm) と MMA との重合によって得られた $\mathrm{PMMA}-\mathrm{SiO}_{2} \mathrm{HBD}$ は, シリカ含有量が $50 \mathrm{wt} \%$ 程度までは透明で, 熱安定性, 弾 性率と表面硬度に優れている ${ }^{19,20)}$.

Bourgeat-Lamiらは,スチレンにMPSを乳化重合し, ポ リスチレン表面にシラノール基をもったコアーシェル構造 を有する複合材料 (ポリスチレンラテックス)を合成し, 架 橋剤やシリコンゴムの室温加硫への応用について検討して いる ${ }^{21)}$.

PMMA -シリカナノ複合材料は, 良好な透明性を保ち ながら耐熱性, 機械強度, 表面硬度などを向上させること ができ，耐候性塗料 22 やコーティング剂23) として商品化 されている.さらに, 要求特性に応じた分子設計や機能性 付与を行うことによって成形材料, ハードコーティング剂 の他多種多様な機能性工業材料として更なる展開が期待さ れる。

\section{4.おわりに}

有機一無機ナノ複合材料の開発が始まって 20 年余りが 過ぎた。この間に数多くの複合材料が開発され，すでに工 業化されたものも多い. 今後, 有機一無機ナノ複合材料が 本格的な展開を図る上で解決しなければならない課題も未 だ多く残されている。

有機一無機ナノ複合材料の今後の発展に必要と思われる 課題のいくつかを以下に述べて本稿のまとめとしたい.

(1) ナノ構造制御による製造技術確立

これまで多くの有機一無機ナノ複合材料が合成されてき

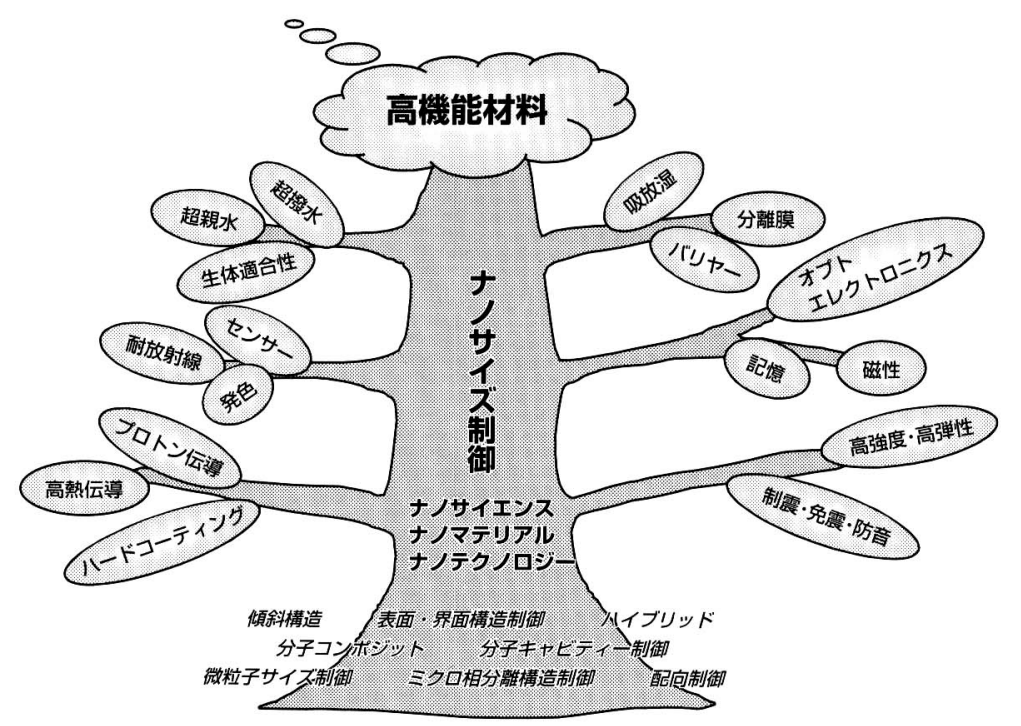

図 9 高機能材料の創製 
たが，その合成法，ナノ構造，材料特性との相関関係が包 括的に整理され解明されていない. これを行うためには基 礎的なデー夕の集積と整理が必要であり膨大な時間と労力 が求められるが，この関係が整理され画一的に理解できれ ば, 要求特性を満足させる材料の設計が容易に行えること になる。

\section{（2）無機成分の分散・界面制御技術確立}

優れた特性を有する有機一無機ナノ複合材料の合成には 無機成分の分散・界面制御技術の確立が必要となる.この 技術確立によって熱特性や力学特性のみならず, 新規な機 能をもった高機能材料開発が可能になる.

\section{（3）ナノ微粒子の製造技術確立}

長期安定性に優れた無機酸化物微粒子や機能性を有する 表面修飾微粒子(特に有機溶媒分散ゾル)の製造技術の確立 が必要である. 無機酸化物微粒子はケイ酸ソーダ (水ガラ ス）または金属アルコキシドの加水分解(ゾルーゲル反応） によって製造されるが，有機溶媒分散ゾルは表面積が大き いため表面活性が高く, 粒子間の凝集や溶媒の分解を起こ すため長期安定性に劣る.Adachiらは超音波を使った非 アルコール溶媒中でのゾルーゲル法球状シリカ微粒子の合 成法を報告しており興味ある方法である ${ }^{24)}$.

（4）機能付与による新規な機能性材料の開発

現在までの有機一無機ナノ複合材料の多くは，熱特性や 機械特性，表面特性を応用した成形材料，塗料，コーティ ング剂など汎用的な工業材料への応用が主なものであっ た. 今後は，有機一無機ナノ複合材料の熱・機械・表面特 性などの基本的特性を活かしつつ，光，電気・電子・分離 などの機能を付与した新規高機能材料を開発し, 新たな応 用分野への展開が期待される ${ }^{25)}$ (図 9 ).

\section{References}

1 ) "Yuuki-Muki Nanofukugouzairyou no Shinkyokumenn", NTS, Tokyo (2004)

2 ) Chujo, K.: "Polymer kei Nanocomposite", Kogyo Cyosakai, Tokyo (2003)

3 ) "Tokusyu=Yuuki-Muki Haiburiddo" Kobunshi, 48(4), (1999)

4) Sakka, S.: "Zol-Gel hou no kagaku", Agunesyofusya, Tokyo (1988)

5 ) Yano, S.: Kinouzairyou, 18(5), 31 (1998)

6 ) Oguchi, T., Sakai, J., Yoshino, A., Suzuki, T., Yamada, Y.: Polym. Prepr. Jpn., 54, 704 (2005)

7 ) Chang, T.C., Wang, Y.T., Hong, Y.S., Chiu, Y.S.: J. Polym. Sci., Part A, Poly. Chem., 38, 1972 (2000)
8 ) Chan, C-K., Peng, S-L., Chu, I-M., Ni, S-C.: Polymer, 42, 4189 (2001)

9 ) Maeno, M., Sakai, J., Oku, J., Suzuki, T., Yamada, Y.: Polym. Prepr. Jpn., 54, 1117 (2005)

10) Hu, Y-H., Chen, C-T., Wang, C-C.: Polym. Degrad. Stab., 84, 545 (2004)

11) Kawai, M.: Toa Gosei Kenkyu Nenpou, TREND 2002(5), 2 (2002)

12) Morgan, B., Antonucci, M., Vanlandingham, M. R., Harris, R. H., Kashiwagi, T.: Polym. Mater. Sci. Eng., 83, 57 (2000)

13) Aruchamy, A., Blackmore, K. A., Zelinski, B. J. J., Uhlmanm, D. R., Booth, C.: Mat. Res. Soc. Symp. Proc, 249, 353 (1992)

14) Kashiwagi, T., Morgen, A. B., Antonucci, J. M., VanLaqndingham, M. R., Harris, R. H., Award, W. H., Shields, J. R.: J. Appl. Polym. Sci., 89, 2072 (2003)

15) Ito, M., Sawaguchi, T., Hagiwara, T., Yano, S., Muruga, Y.: Polym. Pepr. Jpn., 53, 3799 (2004)

16) Yu, Y-Y., Chen, C-Y., Chen, W-C.: Polymer, 44, 593 (2003)

17) Liu, Y-L., Hsu, C-Y., Hsu, K-Y.: Polymer, 46, 1851 (2005)

18) Liu, Y-L., Hsu, C-Y., Wang, M-L., Chen, H-S.: Nanotechnology, 14, 813 (2003)

19) Kubo, Y., Suzuki, Y., Nakanishi, E., Sugimoto, H.: Jpn. Kokai Tokkyo Koho 2004-256753 (2004)

20) Sugimoto, H., Nakanishi, E., Ogasawara, Y., Ebihara, K., Suzuki, Y., Ogino, T.: Polym. Prepr. Jpn., 53, 3723 (2004)

21) Bourgeat-Lami, E., Tissort, I., Lefebvre, F.: Macromolecules, 35, $6185(2002)$

22) Ukaji, T.: Kinouzairyou, 19(7), 34 (1999)

23) Sakagami, T.: Kougyouzairyou, 46(8), 57 (1998)

24) Adachi, K., Iwamura, T., Chujo, Y.: Chem. Lett., 33, 1504 (2004)

25) Comez-Romero, P., Sanchez, C. Eds.: "Functional Hybrid Materials", Wiley-VCH (2004)

\section{日本語表記参考文献}

1) 有機・無機ナノ複合材料の新局面, エヌ・ティー・エス, 東京 (2004)

2 ) 中條澄：ポリマー系ナノコンポジット, 工業調查会, 東京 (2003)

3 ）特集=有機・無機ハイブリッド，高分子，48，(4)（1999）

4) 作花済夫：ゾルーゲル法の科学, アグネ承風社, 東京 (1988)

5 ）矢野彰一郎：機能材料, 18(5), 31 (1998)

6 ）小口雅央, 酒井純, 吉野明広, 鈴木智幸, 山田保治：高分子学 会予稿集，54，704 (2005)

9 ）前野真男，酒井純，奥淳一，鈴木智幸，山田保治：高分子学会 予稿集，54，1117 (2005)

11）河合道弘：東亜合成研究年報, TREND 2002(5)，2（2002）

15）伊藤美津子，澤口孝志，荻原俊紀，矢野彰一郎，室賀嘉夫：高 分子学会予稿集，53，3799 (2004)

19）久保泰男，鈴木康史，中西英二，杉本秀樹：特開 2004-256753 (2004)

20）杉本秀樹, 中西英二, 小笠原裕, 海老原健治, 鈴木康史, 荻野 智也：高分子討論会予稿集，53，3723(2004)

22）宇加地孝志：機能材料, 19(7), 34 (1999)

23）坂上俊規：工業材料, 46(8), 57 (1998) 